FACTA UNIVERSITATIS

Series: Law and Politics Vol. 15, N 4, 2017, pp. 277 - 290

https://doi.org/10.22190/FULP1704277S

Original Scientific Paper

\title{
GREENING ECONOMIES: \\ A NORMATIVE CHALLENGE IN INTERNATIONAL RELATIONS
}

\author{
UDC 502.14
}

\section{Miroslav Stevanović, Dragan Đurđević}

\author{
National Security Academy, Belgrade, Republic of Serbia
}

\begin{abstract}
In this article, we examine the concept of "greening economy" from the aspect of the interest of States as actors in international relations responsible for providing vital values of political communities. The problem in this context primarily involves the nonexistence of consensus about either normative or value content of the "greening economy", apart from a commonly acceptable discourse on the practical level. Nevertheless, such discourse has not been functionalised through new developments in instruments and mechanisms of administration, governance and validation of efforts in numerous sectors at the international level. On the methodological level, the basic dichotomy between the practical and perceptive in the concept of greening economy has imposed a need for phenomenological approach in estimating its functional roles. In this segment, we pursued the obvious appearance or impacts in practice, regardless of the narratives. As far as the discourse itself is concerned, this analysis did not require a detailed insight into perception since different bodies and states apply the concept as they find suitable for their purposes. In the structural analysis, since the greening of economy, as a concept, introduces series of bodies and institutional procedures dealing with measurements, criteria, indicators and tools that impose administering on a supranational level, we have focused on the context of the globalisation process. Besides, these indicators mostly do not lead to the projected goals, nor affect the economy as a whole and achieving sustainable development goals. We find that mainstreaming the environment into economic development, through 'green economy', regardless of how logical in substance it may be, is still no more than an emerging theoretical discourse, which is suitable for the needs of globalisation. We thus conclude that "greening" is a contemporary political economy, which deals with unsustainability on the production level, and lacks a clear definition of development. This concept promotes an administrating process on the global level, without legal grounds, which is a challenge for national security, given that national authorities should be responsible for sustainable development, as a vital value.
\end{abstract}

Key words: natural resources, ecological modernisation, green policies, environment sustainability, economic security.

Received Avgust 21 ${ }^{\text {st }}, 2017$ / Accepted November $20^{\text {th }}, 2017$

Corresponding author: Dragan Đurđević, PhD, Assistant Profesor, National Security Academy, Belgrade E-mail: djurdjevic.dragan@gmail.com 


\section{INTRODUCTION}

The term „green economy“ was coined by a group of economists (Pearce, Markandya and Barbier) commissioned to advise the UK Government about the definition of sustainable development and its implications for measuring of economic progress, in their 1989 report titled „Blueprint for a Green Economy“. In 2008, in the context of the then exploding financial crisis, the United Nations Environment Programme (UNEP) launched the Green Economy Initiative and, within it, in 2009 released a report „Global Green New Deal". This report sets the following objectives: economic recovery; poverty eradication; reduced carbon emissions and ecosystem degradation; and a proposed framework for green stimulus and supportive domestic and international policies. In 2010, the UNEP's Global Ministerial Environment Forum acknowledged that green economy concept can "address current challenges and deliver economic development opportunities and multiple benefits for all nations", recognized the UNEP's leading role in defining and promoting the concept, and encouraged the UNEP to contribute to the preparatory process for the UN Conference on Sustainable Development (Rio+20).

The UN General Assembly decided that the green economy would be included in two themes for Rio+20: in the context of sustainable development and poverty eradication, and within the matter of institutional framework for sustainable development. ${ }^{1}$ This provided international attention for the green economy and related concepts and resulted in numerous reports and literature aiming to define the concept. One of the key reports released by the UNEP, in partnership with think-tanks and commercial actors, accepts a working definition of green economy as "improved human well-being and social equity, while significantly reducing environmental risks and ecological scarcities" (UNEP, 2011: 2). A series of publications elaborate on this concept, but there is no universally accepted definition of green economy; thus, separate definitions were proposed. For example, a group of NGOs, trade union groups and others doing grassroots work on a green economy have defined green economy as "a resilient economy that provides a better quality of life for all within the ecological limits of the planet" (Green Economy Coalition, 2012: 8)

In accordance with the commitment proclaimed at the Rio Summit (1992), sustainable development policies of states should cover the numerous fields and parameters, including transport, energy, land use, water resources, forestry, fish resources, climate change, depletion of the ozone layer, deposition of acids, air quality, drinking water, sea, wild animals and habitats, land and the landscape, arable land, waste management; and radioactivity. The principle problem concerning greening is achieving sustainability between actions and consequences. Empirical logic indicates that sustainability starts from the economic dimension.

\section{MANAGING SUSTAINABILITY}

The value system of capitalism is undermined by its greedy and corrupt (neoliberal) variety (Bratton; Denham, 2014: 381), in which the lack of competition is perceived as successful competitiveness (Qualls, 2014: 36); thus, the free market, as the principle

\footnotetext{
${ }^{1}$ Para. 20(a), UN General Assembly Resolution „Implementation of Agenda 21, the Programme for Further Implementation of Agenda 21 and the outcomes of the World Summit on Sustainable Development", A/RES/64/236 (31 March 2010).
} 
value, is increasingly turning out inadequate to solve root problems of the current financial crisis (McGowan, 2016: 58)

No state alone can solve the problems of the global environment. The global nature of environmental problems has brought this matter in relation with globalisation. The state as such suffers twofold limitations: internally, under the influence of the transformation of the public sector; and externally, under the influence of economic and political globalisation (UNDESA, 2001: 88-89). The consequently arising pluralist concept of stakeholder management, thus, collides in the decision-making process with the neo-elitist, in the sense that there is a need to provide balance between interest groups and businesses (neopluralisam).

The development, as more practically oriented, gains priority in control of resources over sustainability. As such, it also empowers professionals with instrumental reasoning, which generally increases the inequality. Therefore, green discourse conceptualises development on the global level as inherently colonial.

Green discourse, however, contributes to the critique of techno-scientific growth from the aspect of the biological life and also the decentralisation of power. The initial impetus of green discourse is a normative imperative. But, the focus on greening is not sufficient to provide a clear differentiation of green policies, and the green limitations may therefore be perceived as a means of imposing discipline in international relations.

Social greens, like the ecologists, introduce a doctrinal view about the method of achieving sustainability (Blewitt, 2015: 28-29). Sustainability implies retaining of natural wealth and natural capital. In that context, the core of the problems facing sustainability are unsustainability, uncertainty, nonreversibility and inequality.

\section{CONTEXTUALISING PERCEPTIONS}

In international relations, sustainable development is becoming a guiding principle. The paradigm of development is implemented through policies of extracting natural resources, and relies on the security of economics, not on the environment.

Operationalising sustainability politics reflects a general practice attributed to neoliberalism, in the sense that mentalities and behaviours are governed by a discourse on truths. Interiorisation of proclaimed values and normative content are imposed by technologies of power, which discipline individuals through self-regulation of behavior in accordance with biopower as a wider objective (Fletcher, 2010: 172). The neoliberal discourse of nature generally marginalises knowledge. Namely, the construct of environment is operationalised as a series of production characteristics which can be "calculated, organised, technically designed" and "invested with the power relations", and functionalised as a vehicle towards a subordination, around those characteristics (Sullivan, 2013: 211).

The approach to environmental dimension of sustainability is embodied in three trends: a) concern for the environment; b) protection of the environmental in relation to economic growth; and c) public policy and behaviour in harmony with the environment. Ecological management, within such global approach, becomes internationally standardised through a system of environmental management (ISO 14001, 2004), a concept to promote the environmental performance (procedures and objectives) of organisations. This system is based on a risk assessment, by identifying environmental aspects and impacts of activities of an organisation. In the context of environmental concern, the organisations need to provide a 
permanent influence on the development of expertise and awareness of environmental protection, introduce environmentally friendly technologies and processes and introduce measures that enhance prevention of harm to the environment. In the practical context, the causes of environmental threats are induced by modernisation, development, global environmental management, technology transfer and methods of funding, which all strengthen the hegemony of developed countries, large corporations and international financial agencies.

The Rio+ Conference adopted the resolution in which an issue becomes understanding of "green economy", either in terms of the application of environmentally friendly technologies, or as a paradigm shift in favour of social equity and quality of life over economic growth. The green economy is regarded as a tool for achieving sustainable development, which can provide options for policy making, and should not be a set of rules. It should contribute to eradicating poverty and be supportive of economic growth, social inclusion, human wellbeing and opportunities for employment and decent work for all, while maintaining healthy ecosystems.

Yet, the approach and principles of sustainable development, framed by the International Institute for Environment and Sustainable Development in the post-Rio+ process, ignored the green economy. Instead, they follow the paradigm that sustainable development stems from the uniform prosperity and opportunities; healthy and productive natural systems, democratic governance and economic progress, as a basis (Geoghegan, 2013: 2-3). For activities related to sustainable development to have concrete meaning and bearers, they are scaled spatially, and based on the spatial scales a socio-political hierarchy is established (Anderson, 2015: 227).

In the essence of the argument in the discourse of the social greens are the nature's limitations to growth. This concept rejects capital seen as the expression of the accumulation of goods producers, consumers and the number of people. Such approach requires a reorientation of the market economy into an environmentally benign and socially feasible form. The ideal of social greens is to establish common goals and joint real and/or personal needs. For the greens, social value approach is an imminent obligation of the rich "to live more simply so that the poor may simply live".

\subsection{Mechanisms of global contextualisation}

The mechanisms through which the concept of greening economy is conextualised can be derived from global practices. They encompass efforts to manage desired practices and interpretations in certain fields of life. Their common characteristic is that they project desired ideological influence and control on the relations at the global level, outside of formal international legal framework.

\section{- Global Environment Facility}

The Global Environment Facility (GEF) is designed as a financial mechanism for the Convention on Biological Diversity, the Framework Convention on Climate Change, the Convention on the Constant Organic Pollutants and the Convention to Combat Desertification. It also facilitates the implementation of the Montreal Protocol on Substances that Deplete the Ozone Layer in transitional economies.

The GEF is not an international organisation and has no capacity to enter into international treaties; thus, its agreements with States are not subject to ratification.

\footnotetext{
${ }^{2}$ Para. 56, UN General Assembly resolution „,The Future We Want“, A/RES/66/288 (11 September 2012)
} 
Nevertheless, its guidelines have been expanded so that it also supports projects in the particularly vulnerable regions, launches pilot and demonstration projects which can be integrated into national policies and planning for sustainable development, provides funding for capacity building in preparedness and planning for cases of natural disasters, and establishes and strengthens the existence of a rapid alert system for cases of weather disasters. $^{3}$

\section{- International business}

Education for international business is promoted by programs created by NGOs from developed countries (Conner, 2011: 301). New business models introduce aggressive distorted accounting and bookkeeping reports (creative accounting) and impact the conduct in trading (Elliott; Elliott, 2011: 151).

The political coherence generally extends through multilateral institutions and organisations related to international trade and finance. Most obvious is the harmonisation of procedures, policies and overlapping mandates of multilateral development banks, the IMF, the World Bank and the WTO (Auboin, 2007: 4). An example of coherence in the international system is a mechanism in the field of forestry. The supreme authority responsible for planting and preservation of forests and for spreading monoculture as an agricultural production is Food and Agriculture Organisation (FAO), the UN specialised agency. Another UN specialised agency, the World Bank, has the mandate to directly promote these goals within the programs such as: the Clean Development Mechanism and the Prototype Carbon Fund (under the Kyoto Protocol), loans for afforestation in infrastructure projects, and the influence of structural adjustment in the context of the creation of conditions for afforestation. Another UN specialised agency, the International Finance Corporation, directly financially supports the private sector for business in the global South, with an aim to reduce poverty and improve the lives of people through the development of the private sector. Certification of monoculture, and thus licensing the cutting, is within the scope of the Forest Stewardship Council, established in 1993 as a transnational multi-stakeholder body. In 2000, in order to improve the management, conservation and sustainable development of all types of forests, except the monoculture plantations, the UN Forum on Forests was established, which in practice advocates fast-growing plantations, which is exclusively a commercial interest. A regional international organisation, the Inter-American Development Bank, has launched the Investment attractiveness index, which ranks countries according to the economic attractiveness of the forest sector. The global institutional network of impacts in the field of forestry also included the organisations that mediate between international and private sectors. Among the best known are: the World Business Council, a coalition of 150 private companies; the International tropical timber organization, established under the auspices of the UN to balance the interests of logging and conservation of tropical forests; bilateral aid agencies; and consulting firms that provide links between the executive services suppliers, technology providers and equipment manufacturers. In the global South, where land is cheap, workers low-paid and growth rapid, plantations of monoculture are encouraged in practice, which enables low-cost commercial felling. Extensive planting of monoculture forests threatens the grassland, farmland and natural forests, resulting in impoverishment, concentration of land ownership, the degradation of the environment and the non-realisation of the interests of the local population, which is contrary to the declared goals of sustainable

\footnotetext{
${ }^{3}$ Art. 1, Conference of the Parties of the Framework Convetion on Climate Change Decision 6/CP.7 „Additional Guidance to an Operating Entity of the Financial Mechanism“, FCCC/CP/2001/13/Add.1. (10 November 2001)
} 
development. The analysis of the World Bank's investment activities related to the reduction of carbon emissions in developing countries also leads to the conclusion that priorities of the international business system are not elimination of poverty and sustainable development, as the priority appears to be the gain of investors, and the projects are in many cases a threat to the health and lives of the poorest and most vulnerable communities, and sometimes increase global emission (Redman, 2008: 3-5).

\section{- Globalised economy challenges}

Economic globalisation leaves politics behind and in some way changes the role of States, since many important issues transcend national boundaries. At the international level, there are still no democratic institutions that would effectively face the problems created by the globalisation. The international standard is that a daily commitment of the executive authorities should be expressed through a national strategy. Part of the globalist doctrine, however, introduces into the discourse the crucial importance of leadership. Such is, for example, the thesis that "for sustainability, ministries and administrative bodies depend on whether they have the support of the prime minister at all levels of government, local, national. Strategies are the only documents imposed from the top downwards" (MacNeill, 2007: 21).

\section{- Population}

Demographic factors, combined with a lack of access to resources, and excessive consumption and wasteful production patterns in others, cause or aggravate the problems of environmental degradation and loss of resources. ${ }^{4}$ Internationally, liability in connection with this problem is increasingly on the citizens. This process is manifested in the field of social ecology, in which it entails, for example, a form of control of property, similar to land reforms in states. The general result is a trend of expansion of economic freedom, which creates conditions for the strengthening of transnational corporations.

\section{- Global administering of interest}

Dubious is the ability of the global system to administer interests, face challenges and enable mankind to survive and prosper. As another noted weakness of the current global regimes, the Western economic paradigms do not respect the complex problems of natural resource management, nor support the sustainable solutions. In resource management, they prioritise the right of access to natural resources and their use, and in practice they achieve only small and isolated successes (Rydin, 2012: 12).

The environment came to the international agenda in 1967 when the UN General Assembly proposed a conference on the environment. It was recognised that, in the postcolonial period, developing countries may oppose something that could be perceived as a Northern agenda ("green imperialism"). Existing international organisations already had a number of responsibilities in respect of large parts of the environment, but it was recognised that these functions are performed in isolation, as well as the need for establishing a common direction and coordination, and the States have accepted that there are important issues uncovered.

\footnotetext{
${ }^{4}$ Para. 3.25, UN General Assembly resolution „Report of the International Conference on Population and Development“, A/CONF.171/13 (18 October 1994)
} 


\section{- Problem of sustainability}

Atmospheric changes, destruction of ecosystems, pollution of the biosphere and the costs of cleaning pose a global threat. The struggle for resources and survival also gets its forms within social groups, religions, ethnic groups and business circles. The subject of the struggle, on the globalised market, becomes the access to non-renewable resources. The effort is to suppress competition through the inclusion of companies in globalisation of distribution and exploitation.

This process is shaped by international structures that occur in response to specific questions of globalisation under the leading influence of the United States (Friedman, 2005: 400). In addition, globalisation is an objective process in the development of nature and society, which takes into account the global population dynamics (Krapivin; Varotsos, 2007: 2).

\section{- Indicators}

Sustainability indicators can be subsumed under two broad methodological paradigms. One has epistemological roots in scientific reductionism; it is characterised by the pursuit of quantitative indicators, which enable the quantification of the complexities of dynamic systems but do not reflect the complexities of a series of options for the users of resources. The second is based on the philosophy of parsing, cultural anthropology and social psychology; it entails social activism, adult education and the importance of local communities in determining the objectives and defining priorities. The formalisation of the application of these indicators is part of a broader community involvement in environmental management and a response to the failures of the bureaucratic (top-down) interventions (Dougill; Reed, 2016: 35-36).

The problem in determining the indicators for measuring progress leads to different perceptions. The result is the development of sectoral criteria, which are supported by reporting on indicators, as a basis for management at a national and international level, within which is, as a corrective mechanism, advocated participatory decision-making (Quinn; Marriot, 2016: 80-81).

\section{- Education}

Education related to the environment is accepted as a way to affect change in attitudes and behaviours necessary to encourage respect for nature (Ferguson; Thomas-Hope, 2016: 92). The paradox is that environmental education is proclaimed essential for sustainable development, while concurrently it may play a part in establishing an unsustainable society (Sterling, 2014: 18). The practical significance of conceptualisation of education for sustainable development at the international level stems from the fact that, if a projected discourse of sustainable development incorporates a hegemonic construct of nature, the education system will necessarily be institutionalised in a way that the dominant values and knowledge are veiled. Formalising the curriculum of the still conceptually vague concept of sustainable development, which turns into the mainstream, threatens to educate brokers and objects instead of subjects for change. The discourse of education for sustainability promotes as key themes: lifelong learning, interdisciplinarity, partnership, multiculturalism and empowering (Ahmia, 2012: 373)

\section{- Public administration}

Environmental sustainability depends on the perception of the results of human actions. Today's trend is the model of organisation which dogmatises efficiency, measurability, 
predictability and control to master an increasing number of segments of society. Through it, new life receives dogmas of public administration, such as effectiveness, efficiency, reactivity, and fairness (Leuenberger; Bartle, 2015: 15).

The roles of private and public stakeholders in the planning of sustainable development relativise privatisation. Responsibilities of public and private organisations are increasingly equivocal but they can work together; the most significant are non-governmental and nonprofit organisations which apply strategic planning and structuring commitment to sustainable development. The vital factor is the decision based on the available data, which also encourages research. The importance of educational institutions for public administration, except for the decision making, is reflected in the formation of a broad front for eligibility decisions.

\section{- Human security}

The concept of human security, which focuses on global concern and ethical individual, modifies the concept of national security and the concept of development. In international politics and international relations, human security in the context of sustainable development can occur as a critical concept, as the activistic concept' or even as a focus. Activist organisations are not accountable to citizens, but to international donors and statisticians. This causes depoliticization, since they are not subject to competition. As a consequence, the shift of emphasis to ability and individual responsibility ignores broader social structural causes and, therefore, inevitably fails to be determined in relation to the basic causes, favouring inspection results.

\section{- Institutional framework}

The fact that the State has become inadequate to optimally solve certain scope of problems is reflected in the transfer of management to the regions and local communities (Marks; Hooghe, 2005: 27-28). The idea of social responsibility becomes the governing principle of socialisation, and it is based on the paradigm of individual responsibility for social objectives (Kamens, 2012: 63) and, further, the concepts of organised individuals and reducing the legitimacy of hierarchical structures. At the same time, the public sector shows little ability to resist the influence of big business on government policy (Reilly, 2014: 71).

\section{- National strategies}

The Summit in Johansburg called on governments to take immediate steps for progress in the formulation and elaboration of national strategies for sustainable development and to begin their implementation by $2005 .^{5}$

\section{GREENING THE CONCEPT OF DEVELOPMENT}

From the context of pragmatism stems criticism of ecological economics, as a model which does not infringe the essence of the problem of the unsustainability of the overall economic system. "Eco compatible capitalism is unrealistic in practice. The market system, dominated by large multinational corporations will never go the way eco capitalism own initiative ... A society based on economic contraction cannot exist under capitalism..." (Latouche, 2006) Descending growth is compatible with the constant valorisation of the

${ }^{5}$ para. 162(b), UN General Assembly resolution „Report of the World Summit on Sustainable Development“, UN doc A/CONF/199/20 (4 September 2002) 
economic value relation and, thus, practically committed to reforming on the principles of current economy. Consistently carried out, the discourse of declining growth comes down to the idea that the environmental costs may be internalised within the present capitalist economy (O'Connor, 1994: 127-133). In this context, the environmental crisis remains only as a common problem of mankind, due to degradation of the environment, without taking into account that its consequences are primarily sustained by lower social groups.

International assistance is considered to be an essential tool for achieving sustainable development. Nevertheless, the development challenges and the rifts survive, whereas the prolonged economic crisis has caused a further setback.

On the global level, executive authorities and companies coordinate efforts through partnerships and participational organisations dealing with different issues: protection and restoring natural habitats and species necessary for maintaining ecosystems; management of risks to the health of the ocean, including pollution from land and from the extractive industries; management of lawful fishing and sustainable agriculture; fostering global advocacy of sustainable communities and economies resistant to climate; and sharing knowledge on innovations and technological solutions (Freestone, 2012: 4-5; Wouters; Ninio; Doherty; Cisse, 2015: 123-125). This approach has resulted in broadening the conceptual base with terms based on ethical values (Minch, 2009: 323-343).

\subsection{Greening through economic security}

The environmentalist movements campaign on various issues, including raising awareness of environmental and global justice, green consumerism and green policies aimed at the dignity of all living species. The environmental protection discourse influenced the launch of antiglobalization protests. The image of an "eco-warrior" expands into a network of activists, integral in the contemporary political iconography. Within this discourse, in developed countries, the conceptualisation of sustainable development recognizes "ecological modernisation“ (Barry, 2010: 112).

The discourse of economic security can be used to articulate a normatively binding and politically relevant definition of an economy in harmony with the needs of nature, as the foundation of a modern state and market forms of sustainable development based on the acceptance of the necessity of green policies. The need for a healthy environment has become a widely accepted argument, whereby economy needs to be more efficient in the use of resources and has to minimise pollution and waste. Yet, the central aspect of ecological modernisation is missing, the concept of innovation and efficient production methods, as a segment in the administering process that will ensure ecological efficiency and ecological modernization of the economy. Another drawback is related to articulation of the nonecological demands of "green" policies, which should provide a change of discourse from economic growth to economic security, sustainable distribution based on values such as justice, egalitarianism, democratic organisation of the market and the conceptual expansion of political economy to encompass social and non-cash economic activity and the role of the state (Barry, 2010: 123-126).

Reliance on social line enables differentiating policy building on the environment and ecology. The argument for such economic policy is based on economic security and constitutes the acceptable discourse of the constraints on growth. This discourse, however, is often politically expressed as "tackling climate change and other challenges to the environment without limiting major economic opportunity ... economic development, social 
justice and environmental modernisation, which must go together" (UK Prime minister's Office, 2003). This rhetoric follows an idea that sustainability is linked to environmental management and efficiency and competitiveness of the economy. Thus, the policies of environmental protection and economic modernisation get the role of political purposes, at the expense of ecological restructuring; therefore, there is a limited reform shift (Mol; Spaargaren, 2013: 38).

The criticism that ecological modernisation of economy ignores the patterns of consumption has generated an approach that aims to achieve economic security, which implies sustainable production and sustainable consumption. The central aspect of the ecological modernisation of the economy is the reduced role of the State in coordination and support of technological innovation, and greater economic and environmental efficiency in using natural resources and energy. Findings indicate that the happiness index, measured on the basis of satisfaction with the quality of life and equality, is greater in countries that provide economic security. From this, it is concluded that economic security promotes population happiness (ILO, 2004: 1). These findings provide empirical support for the green policy argument, that the priority should be to increase human well-being and quality of life rather than conventionally understood economic growth. Social greens seem to correctly observe that democratic political system does not include connection to the growing levels of consumption and to the principles of democracy and egalitarianism which should (by its characteristics of common citizenship of the Planet, plurality of interests, socio-economic and socio-political equality) form part of a democratic culture, important for sustainable development.

\subsection{Economic aspect}

Today, the agencies in the UN system are coming to the conclusion that the Earth can support the current population, but the life-support systems necessary to achieve this are seriously disturbed (Rogers; Jalal; Boyd, 2008: 21). Given that a common key to sustainability is identified through indicators of human savings, created and natural capital (Kaneko, 2016: 192), sustainability can be pursued through multiple approaches.

An important issue is the existence of a permanent compromise between economic growth and environmental sustainability. Applied to corporate governance in environmental matters, the direction must be to reach a situation in which a company operates in a manner that is consistent with the concept of sustainable development. The corporate approach to managing issues related to the environment depends mainly on the culture and the system in which corporations operate.

Natural resource management involves making decisions about the composition of the capital, which includes human capital, produced capital and natural resources. The problem of the common good is that it does not exist as an individual freedom. Due to the lack of sanctions, individual economic interests have primary impact in decisions on the common good. Otherwise, sustainability should not impose the reshaping of markets and production processes in accordance with the logic of nature, given that it relates to nature and people.

Proponents of environmental protection set a broader issue: whether an economic growth is generally desirable; it has genereated a new terminological differentiation of "ecologically sustainable development", in which development represents a qualitative growth. Sustainable development is an attempt to reduce the impact of politics in decision- 
making, by artificially replacing conflicts with consensus, related to environmental protection and economic development. This implies the inclusion of a series of working and interest groups. The result is that industry and technology are perceived as part of the solution to problems in the environment context rather than as the cause of trouble. Access to consensus provides the status quo on the business level. Nature and environment impose imperatives that are drivers of social and political changes. These imperatives are, however, deconstructed through the idea of sustainable development. So, as long as the public believes that sustainable development can ensure the protection of the environment, there is no possibility for discussion on alternatives, and the lack of discussion reinforces the idea that the existing system is the only possible one (Beder, 2006:6).

\subsection{Risks of institutionalisation}

The concept of private conservation of the World Bank was designed in 1987 as a means to facilitate the transfer of debts of the Third World countries to this institution; in turn, these countries would give land to the World Bank as collateral (Salih, 1997:126), which would be illegal (Kumhof; Tanner, 2008: 267).

The GEF included government officials from 179 countries, creating the illusion of an international organisation. Within the GEF, they work in partnership with international institutions, non-governmental organisations and the private sector on global environmental issues. Today, the GEF is the largest funder of projects aimed at improving the environment in more than 2,400 projects in over 165 developing countries (Ramutsindela, Spierenburg, Wels, 2011: 106). The GEF partner agencies are the UNDP, the UNEP, the World Bank, the UNFAO, the UNIDO, the African Development Bank, the Asian Development Bank, the European Bank for Reconstruction and Development, the Inter-American Development Bank and the International Fund for Agricultural Development.

Since the Republic of Serbia got involved and applied for loans, it has received funds for co-financing in ten national projects. Among them, three projects are in the field of biodiversity, one project is in international waters, two projects are related to organic pollutants and one project is in multifocal areas. Serbia has participated in thirteen regional and global GEF projects. Among these are two projects in the field of climate change, nine projects in international waters and two projects in multifocal areas. Between July 2010 to June 2014, Serbia received an indicative allocation of the executive to formulate projects in the fields of biodiversity, climate change and land degradation. In Serbia, an example of a project in the field of climate change is "Support to sustainable transport system in the city of Belgrade", implemented by the UNDP, with funding from the GEF. This project has developed a process to develop links with other UNDP projects on the sustainability of transport 'in the region' (Slovakia and Tajikistan). Besides the issue concerning the basis of factual international cooperation and external borrowing without the consent of the competent representative bodies, it is interesting that the GEF website personalises public officials who are in charge of Serbia's cooperation with this organisation of unclear legal status, by referring to the minister of agriculture (previously it was the minister of environment and spatial planning) "as the political focal point, and one of the assistants in the ministry, "as the operational focal point" (GEF, 2017). 


\section{CONCLUSION}

Global economic administering related to environmental issues seems to be the dominant mechanism of greening. The role of the international financial institutions is limited, in the sense that it includes only situations where environmental problems have consequences on the macroeconomic stability and sustainable growth (IMF, 2000).

There is no rational explanation for the simultaneous occurrence of incredibly adverse consequences of these arrangements for a large number of countries. On the other hand, these consequences are undermining the ability of the executive authorities of developing countries to perform the basic functions for which they legitimately collect taxes from citizens; moreover, they are undermining of ethical values and justice in societies, which negatively impacts the rule of law and sustainable development. Another problem is that the financial and private sectors of developing countries have no access to an investment capital market, which is monopolised by the developed countries. It can be generalised that discourses on the risks of contextualization of greening are, thus, burdened with the possibility of misuse against individuals, uncontrolled influence of capital and its institutionalisation on the global level.

A commonplace in the considerations of the social greens is an assertion that the power structure of modern societies is simultaneously highly exploitative, unjust, oppressive, and generates environmental degradation. These arguments emphasise global imbalances as the key for understanding the global politics, which leads to a conclusion that the dominant political forces apply environmental concerns in order to spread the influence. On the one hand, the social greens' criticism can be understood in the context of the review of sustainable development from a position of accepting constraints on growth but, on the other hand, it may also be understood in the context of conceptualisation of the common good, which gives greening the status of the political economy.

\section{REFERENCES}

Ahmia, M., (2012). The Group of 77 at the United Nations: Environment and Sustainable Development, Oxford, Oxford University Press, p. 373.

Anderson, S., Peterson, M., Toops, S., Hey, J., (2015). International Studies: An Interdisciplinary Approach to Global Issues (3rd edition), Boulder, Westview Press.

Auboin, M., (2007). Fulfilling the Marrakesh Mandate on Coherence: Ten Years of Cooperation between the WTO, IMF and World Bank, Geneva, WTO.

Barry, J., (2010). Towards a Model of Green Political Economy, / In: Leonard L., Barry J. (eds.), Global Ecological Politics /. - Bingley, Emerald Group Publishing, 2010, pp. 109-128.

Beder, S., (2006). Free Market Missionaries: The Corporate Manipulation of Community Values, London, Earthscan.

Blewitt, J. (2015). Understanding Sustainable Development, 2nd edition, New York: Routledge.

Bratton, J., Denham, D., (2014). Capitalism and Classical Social Theory (2nd edition), Toronto, University of Toronto Press.

Conference of the Parties of the Framework Convetion on Climate Change Decision 6/CP.7 „Additional Guidance to an Operating Entity of the Financial Mechanism“, FCCC/CP/2001/13/Add.1. (10 November 2001)

Conner, S., (2011). Why CIBERs Matter to the Competitiveness of U.S. Businesses in the 21st Century, Business Horizons, Vol. 54., No. 4, pp. 299-305.

Dougill, A., Reed, M., (2016). Frameworks for Community-based Rangeland Sustainability Assessment: Lessons from the Kalahari, Botswana, / In: Woodland, W., Terry, A., Hill, J., (eds.), Sustainable Development: National Aspirations, Local Implementation /. - Oxon/New York, Routledge, 2016, pp. 31-50.

Economic Security for a Better World (2004), Geneva, Switzerland, International Labour Office.

Elliott, B., Elliott, J. (2011). Financial Accounting and Reporting (14th edition), Harlow, Pearson Education. 
Ferguson, T., Thomas-Hope, E., (2016). Environmental Education and Constructions of Sustainable Development in Jamaica, / In: Hill, J., Terry, A., Woodland, W. (eds.) /. - Sustainable Development: National Aspirations, Local Implementation, Oxon/New York, Routledge, 2016, pp. 91-114.

Fletcher, R., (2010). Neoliberal Environmentality: Towards a Post-sructuralist Political Ecology of the Conservation Debate, Conservation and Society, Vol. 8, No. 3, pp. 171-181.

Freestone, D., (2012). The World Bank and Sustainable Development: Legal Essays, Leiden: Martinus Nijhoff Publishers.

Friedman, T., (2005). The World Is Flat: A Brief History of the Twenty-First Century, New York, Farrar, Straus \& Giroux.

GEF, Country at a glance, Retrieved 25 August 2017, from https://goo.gl/oyM9Tt

Geoghegan, T., (2013), Post 2015: Framing a New Approach to Sustainable Development, Independent Research Forum Policy Paper, Retrieved 15 August 2017, from https://goo.gl/kDxVEs

Green Economy Coalition (2011), Green, fair and productive: How the 2012 Rio Conference can move the world towards sustainability, Retrieved 15 August 2017, from https://goo.gl/nvkgjm

IMF, The IMF and Environmental Issues, Issues Brief, 13 April 2000, Retrieved 25 August 2017, from https://goo.gl/51p3aV

Kamens, D., (2012). Beyond the Nation-state: The Reconstruction of Nationhood and Citizenship, Bingley, Emerald Publishing.

Kaneko, S., (2016). Sustainable Development, / In: T. Shimaoka; T. Kuba; H. Nakayama; T. Fujita; N. Horii (eds.), Basic Studies in Environmental Knowledge, Technology, Evaluation, and Strategy: Introduction to East Asia Environmental Studies /. - Tokyo/Heidelberg/New York/Dordecht/London, Springer, 2016, pp. 183-193.

Krapivin, V., Varotsos, C. (2007). Globalisation and Sustainable Development: Environmental Agendas, Berlin, Springer Science \& Business Media.

Kumhof, M., Tanner, E., (2008). Government Debt: A Key Role in Financial Intermediation, / In: Reinhart, C., Végh Gramont, C.; Velasco, A. (eds.), Money, Crises, and Transition: Essays in Honor of Guillermo A. Calvo /. - Cambridge, MIT Press, 2008, pp. 249-264.

Latouche, S. (2006). The Globe Downshifted, Le Monde Diplomatique (English edition), 13 January 2006, Retrieved 25 August 2017, from http://goo.gl/99i4Yo

Leuenberger, D., Bartle, J. (2015), Sustainable Development for Public Administration (2nd edition), New York, Routledge.

MacNeill, J., (2007). Leadership for Sustainable Development, / In: Institutionalising Sustainable Development I. - Paris: OECD Publishing, 2007, pp. 19-23.

Marks, G., Hooghe, L., (2004). Contrasting Visions of Multi-level Governance, / In: Bache, I., Flinders, M, (eds.), Multi-level Governance /. - Oxford, Oxford University Press, 2004, pp. 15-30.

McGowan, T., (2016). Capitalism and Desire: The Psychic Cost of Free Markets, New York, Columbia University Press.

Minch, M., (2009). The Democratic Theory of Michael Oakeshott: Discourse, Contingency, and 'The Politics of Conversation', Exeter/Charlottesville, Imprint Academic.

Mol, A., Spaargaren, G., (2013). Ecological Modernisation Theory in Debate: A Review, / In: Bache, I., Flinders, M. (eds.), Ecological Modernisation Around the World: Perspectives and Critical Debates /. Oxon/New York, Routledge, 2013, pp. 17-49.

O'Connor, M., (1994). Is Capitalism Sustainable?: Political Economy and the Politics of Ecology, New York/London, Guilford Press.

Qualls, E., (2014), Community Capitalism: Pulling Capitalism Back From Its Own Abyss (2nd edition), Richardson, Danaan Press.

Quinn, N., Marriot S., (2016). Sustainable Water Resourse Management in South Africa: A Decade of Progress?, / In: Hill, J., Terry, A., Woodland, W. (eds.), Sustainable Development: National Aspirations, Local Implementation /. - Oxon/New York, Routledge, 2016, pp. 67-90.

Ramutsindela, M., Spierenburg, M., Wels, H., (2011). Sponsoring Nature: Environmental Philanthropy for Conservation, London/New York, Earthscan.

Redman, J., (2008). World Bank: Climate Profiteer, Washington, Institute for Policy Studies.

Reilly, T., (2014). Rethinking Public Sector Compensation: Whatever Happened to the Public Interest?, New York, Routledge

Rogers, P., Jalal, K., Boyd, J., (2008). An Introduction to Sustainable Development, London/Sterling, Earthscan.

Rydin, Y., (2012). Governing for Sustainable Urban Development, London, Earthscan.

Salih, M., (1997). Global Ecologism and Its Critics, / In: Thomas C., Wilkin P. (eds.), Globalization and the South /. - Basingstoke, Macmillan Press, New York: St. Martin Press, 1997, pp. 124-142.

Sterling, S., (2014). Education in Change, / In: Huckle J., Sterling, S., (eds.), Education for Sustainability, Ebook edition /. - New York: Earthscan, 2014, pp. 18-39. 
Sullivan, S., (2013). Banking Nature?: The Spectacular Financialization of Environmental Conservation, Antipode, Vol. 45:1, pp. 198-217.

UK Prime Minister's Office, Prime Minister's speech on sustainable development, 24 February 2003. Retrieved 25 August 2017, from http://goo.gl/E00T0w

UN General Assembly Resolution „Implementation of Agenda 21, the Programme for the Further Implementation of Agenda 21 and the outcomes of the World Summit on Sustainable Development", A/RES/64/236 (31 March 2010)

UN General Assembly resolution „Report of the International Conference on Population and Development“, A/CONF.171/13 (18 October 1994)

UN General Assembly resolution „Report of the World Summit on Sustainable Development“, UN doc A/CONF/199/20 (4 September 2002) .

UN General Assembly resolution „The Future We Want“, A/RES/66/288 (11 September 2012)

UNDESA World Public Sector Report: Globalization and the State. (2001). New York: United Nations.

UNEP (2011). Towards a Green Economy: Pathways to Sustainable Development and Poverty Eradication - A Synthesis for Policy Makers, Retrieved 25 August 2017, from https://goo.gl/kVqyff

Wouters, J., Ninio, A., Doherty, T., Cisse, H., (2015). The World Bank Legal Review Volume 6 Improving Delivery in Development: The Role of Voice, Social Contract, and Accountability, Washington, World Bank Publications.

\section{OZELENJAVANJE EKONOMIJA: NORMATIVNI IZAZOVI U MEĐUNARODNIM ODNOSIMA}

U ovom članku predstavljamo rezultate preispitivanja koncepta "zelene ekonomije" sa aspekta interesa država kao aktera u međunarodnim odnosima izvorno odgovornih za obezbeđivanje vitalnih vrednosti političkih zajednica. Problem u tom kontekstu prvenstveno obuhvataa nepostojanje konsenzusa o normativnom ili vrednosnom sadržaju "zelene ekonomije", osim obično prihvatljivog diskursa na praktičnom nivou. Takav diskurs, međutim, nije funkcionalisan u novim razvojima instrumenata $i$ mehanizama administriranja, upravljanja $i$ validacije napora $u$ brojnim sektorima na međunarodnom nivou. Na metodološkom planu, osnovna dihotomija između praktičnog i perceptivnog u konceptu zelene ekonomije nametnula je potrebu za fenomenološkim pristupom u proceni njegovih funkcionalnih uloga. $U$ tom segmentu, nastojali smo da sledimo očigledna ispoljavanja ili uticaj u praksi, bez obzira na narativ. Kad se radi o samom diskursu, ova analiza nije zahtevala detaljan uvid u percepciju, jer različita tela $i$ države koncept primenjuju onako kako nalaze pogodnim za sopstvene potrebe. $U$ strukturalnoj analizi, s obzirom da ozelenjavanje privrede, kao koncept, uvodi niz tela i institucionalnih procedura koje se bave merenjima, kriterijumima, pokazateljima $i$, generalno, instrumentima koji nameću administriranje na nadnacionalnom nivou, usredsredili smo se na kontekst procesa globalizacije. Pored toga, ovi pokazatelji uglavnom ne vode ka proklamovanim ciljevima, niti utiču na ekonomiju kao celinu i ostvarivanje ciljeva održivog razvoja. Navedenom analizom, dolazimo do nalaza da integracija životnog okruženja u koncept ekonomskog razvoja, kroz "zelenu ekonomiju", bez obzira koliko je logično u suštini, i dalje nije više od izrastajućeg teorijskog diskursa, koji pogoduje potrebama globalizacije. Stoga zaključujemo da je ozelenjavanje savremena politička ekonomija, koja se bavi neodrživošću na nivou proizvodnje i bez jasnog određenja u odnosu na pojam razvoja. Kao takav, ovaj koncept utiče na razvoj administrativnog procesa na globalnom nivou, bez pravnog osnova što, s obzirom da vlasti države treba da budu odgovorne za održivi razvoj kao vitalnu vrednost, predstavlja izazov za nacionalnu sigurnost.

Ključne reči: prirodni resursi, ekološka modernizacija, zelene politike, održivost životne sredine, ekonomska bezbednost. 